\title{
Industrial Structure and Competitive Strength of the 21 Cities' Tourism in Guangdong Province Based on SSA
}

\author{
Yi Liu ${ }^{1} \&$ Yin Yao ${ }^{1}$ \\ ${ }^{1}$ School of Management, Jinan University, China \\ Correspondence: Yin Yao, School of Management, Jinan University, Guangzhou, Guangdong, China. E-mail: \\ yaoyin654321@163.com
}

Received: January 24, 2015

Accepted: March 4, $2015 \quad$ Online Published: March 27, 2015

doi:10.5539/ijbm.v10n4p203

URL: http://dx.doi.org/10.5539/ijbm.v10n4p203

\begin{abstract}
Based on the date during 2003-2012 about the tourism revenue in 21 local cities and total tourism income and GDP of Guangdong Province, this paper analyzes the structure and competitiveness of 21 cities's tourism in Guangdong with dynamic Shift-Share Analysis. The results show that tourism industries in mountainous areas of Guangdong Province are developing well in recent years, with the structure strengths and competitive advantages of tourism industry in Qingyuan, Heyuan, Meizhou and Yunfu are more obvious. However the trend of competitiveness of tourism industry in Zhuhai, Shenzhen, Foshan and Shantou is gradually declining, the whole structure of tourism industry in Guangdong Province is positive.
\end{abstract}

Keywords: Guangdong province, SSA, the structure of tourism industry, competitiveness

\section{Introduction}

Shift-share Analysis was first put forward by American economist Daniel and Creamer(1943), finally summarized into the widely used current form by Dunn(1960). Now it is not only widely applied in regional economics and urban economics field but has also become one of the effective statistical methods for studying regional economic growth (Chiang, 2012; Márquez, Ramajo, \& Hewings, 2009; Mayor, Matías, \& López, 2008; He, 2012).

Shift-share analysis is a method which takes the change of the regional economy as a dynamic process. This method needs to take its area or the whole country's economic development as a reference, and decompose the changes of the area's own economy during a certain period into three components, namely share component, structure deviation component and competitiveness deviation component, which can explain the reasons for the development and recession of regional economy, evaluate regional economic structure and competitive strength, and set the right direction of the future economic development and the principle of industrial structure adjustment. The method was introduced into China in the 1980s, scholars Zhou qi-ye and Liu zai-xing made a detailed introduction of shift-share analysis earliest (1989), but it was more commonly used in various fields by scholars after the year 2000 (Li \& Zuo, 2010; Mehregan, Asgary, \& Rezaei, 2012; Liu \& Moini, 2015; Hisyam, Rashid, \& Hamid, 2011). In the field of tourism research, some scholars studied the tourism market by applying shift-share analysis (Zhang, 2008; Lv, Wang, \& Gong, 2006; Yasin, Alavi, Sobral, \& Lisboa, 2004), some gave analysis and demonstration on the rationality (feasibility) of the sector structure of regional tourism industry (Yang, Ma, \& Huo, 2005; Hu, Wang, \& Qian, 2008). Scholars also made an analysis of tourism arrivals by purpose of visit through SSA (Toh, Khan, \& Lim, 2004). From the existing literature, it drew the conclusion that most scholars made an analysis by using static shift-share analysis. That is, reasonably selecting a base and end period for study, regardless of the continuous change of industrial structure and regional competition during the study period. Only few scholars have adopted continuous research and analysis. For example, He tian-xiang analyzed the cause of evolution of industrial structure benefit based on the analysis of industrial structure in Hunan Province (He, Zhu, \& Zhou, 2005). Because most of the research is established on the basis of the static analysis, the final research results may overstate the state benefit and competitive situation, which further lead to increase the contingency and unreliability of the analysis results greatly (Yang \& Chen, 2006).

This article will study the tourism industrial structure and competitiveness of 21 cities in Guangdong Province with dynamic shift-share analysis. It chooses Guangdong Province as a frame of reference and the years of 2003, 2006 and 2009 as the base periods, and makes a analysis of 21 cities' tourism competitiveness situation in 
Guangdong Province every three years, which makes the paper more scientific and can dynamically observe the change of the cities' tourism industrial structure and competitiveness. This paper also further provides basis and reference to the development of Guangdong tourism, and explores countermeasures to promote the development of its tourism industry.

\section{Shift-Share Analysis Model}

The principles of dynamic shift-share analysis model are as follows: Supposing the regional economy changed after a certain period of time ( $t$ ), the base period and the end period of the region's economy is $b_{o}$ and $b_{t}$, and supposing there is $n$ sectors in the area, the base period of region's industrial economy is $b_{i o}$, the end period of region's industrial economy is $b_{i t}$, the base period of national $i$ industrial economy is $B_{i o}$, the end period of national $i$ industrial economy is $B_{i t}$, the base period of national GDP is $B_{0}$ and the end period of national GDP is $\mathrm{B}_{\mathrm{t}}$.

The rate of industry (i) in the area for a period of time (t) can be calculated with the formula:

$$
r_{i}=\left(b_{i t}-b_{i o}\right) / b_{i o}(\mathrm{i}=1,2,3 \ldots, \mathrm{n})
$$

The rate of national GDP for period of time (t) can be calculated with the formula:

$$
R_{i}=\left(B_{i t}-B_{i o}\right) / B_{i o}(\mathrm{i}=1,2,3 \ldots, \mathrm{n})
$$

With every sector of the national share after standardization for the study area industry scale, this can be drawn:

$$
b_{i 0}{ }^{\prime}=b_{i o} \cdot B_{i o} / B_{o}(\mathrm{i}=1,2,3 \ldots, \mathrm{n})
$$

In this way, the increment $\mathrm{G}_{\mathrm{i}}$ of industrial sector in period of time $\mathrm{t}$ can be decomposed into three components: $\mathrm{N}_{\mathrm{i}}, \mathrm{P}_{\mathrm{i}}, \mathrm{D}_{\mathrm{i}}$. In other words, $G_{i}=N_{i}+P_{i}+D_{i}$, and $N_{i}=b_{i 0}{ }^{\prime} \cdot R_{i}, P_{i}=\left(b_{i 0}-b_{i 0}{ }^{\prime}\right) R_{i}, D_{i}=b_{i 0}\left(r_{i}-R_{i}\right), P D_{i}=P_{i}+D_{i}$, of which $\mathrm{N}_{\mathrm{i}}$ is share component, namely the changes of regional standardization sector according to the national average growth rate of development; $\mathrm{P}_{\mathrm{i}}$ is the structure deviation component, namely the deviation of regional industrial growth relative to national standard caused by the proportionate difference between regional and national department. The larger this value is, the larger the department's contribution to the economy growth will be; $D_{i}$ is the competitiveness deviation component. That is, the deviation caused by the difference between regional and national $i$ industrial department growth rate, which can reflect the relative competitiveness of regional $i$ industry.

\section{Shift-Share Analysis of Tourism Industry Structure in Guangdong Province}

\subsection{Data Sources and Collection}

This paper selects the last decade's data including 21 cities' tourism revenue, GDP of Guangdong Province and Guangdong tourism revenue from 2003-2012 yearbook of China tourism statistics, China's Statistics Bureau website and Guangdong statistical yearbook, then carries out a comparative analysis on 21 cities' tourism development. Taking Guangdong Province as reference context, this paper sets the base period GDP of Guangdong province for $\mathrm{B}_{0}$, the end period GDP of Guangdong province for $\mathrm{B}_{\mathrm{i}}$, the base period tourism revenue of Guangdong province for $B_{i o}$, the end period tourism revenue of Guangdong province for $B_{i t}$, the base period tourism revenue of $j$ city in Guangdong for $b_{i o}$, the end period tourism revenue of $j$ city in Guangdong for $b_{i t}$, the base period GDP of $j$ city for $b_{o}$ and the end period GDP of $j$ city for $b_{t}$ to study the tourism development situation of 21 cities in Guangdong province.

\subsection{Date Processing}

Under the background of tourism industry situation of Guangdong province, this paper takes 2003 for the base period, 2006 for the end period, takes 2006 for the base period, 2009 for the end period, takes 2009 for the base period, 2012 for the end period, then puts the dates into the above formula, uses the SSA calculation method and process, gets the results into table 1 and finally makes shift-share analysis of 21 cities' tourism industry economic growth.

It studies and calculates tourism industry competitiveness deviation component $\mathrm{D}_{\mathrm{i}}$ of three stages in 2003-2006, 2006-2009 and 2009-2012 and sorts by the tourism industry competitiveness in terms of the base period 2009 and the end period 2012 in table 2.

With the base period 2009 and the reporting period 2012, setting the structure deviation component $P_{i}$ of 21 cities in Guangdong province as the Y-axis, competition component $\mathrm{D}_{\mathrm{i}}$ as the $\mathrm{X}$-axis, drawing the represent marked area in the axis and forming the regional deviation analysis figure 1.

Similarly, according to the date calculated on the basis of the base period 2009 and the reporting period 2012, setting the deviation component $\mathrm{PD}_{\mathrm{i}}$ as the $\mathrm{X}$-axis and share components $\mathrm{N}_{\mathrm{i}}$ as $\mathrm{Y}$-axis, marking the co-ordinates on the axis and forming the regional advantage analysis figure 2 . 


\subsection{Results Analysis}

Table 1. The SSA analysis of Guangdong tourism industry structure

\begin{tabular}{|c|c|c|c|c|c|c|c|c|c|c|c|c|}
\hline & \multicolumn{4}{|c|}{$2003-2006$} & \multicolumn{4}{|c|}{ 2006-2009 } & \multicolumn{4}{|c|}{ 2009-2012 } \\
\hline & $\mathrm{N}_{\mathrm{i}}$ & $\mathrm{P}_{\mathrm{i}}$ & $\mathrm{D}_{\mathrm{i}}$ & $\mathrm{G}_{\mathrm{i}}$ & $\mathrm{N}_{\mathrm{i}}$ & $\mathrm{P}_{\mathrm{i}}$ & $\mathrm{D}_{\mathrm{i}}$ & $\mathrm{G}_{\mathrm{i}}$ & $\mathrm{N}_{\mathrm{i}}$ & $\mathrm{P}_{\mathrm{i}}$ & $\mathrm{D}_{\mathrm{i}}$ & $\mathrm{G}_{\mathrm{i}}$ \\
\hline Guangzhou & 22.29 & 241.63 & -18.2 & 245.72 & 25.14 & 290.09 & -21.02 & 294.21 & 68.79 & 815.91 & 29.82 & 914.52 \\
\hline Shenzhen & 14.43 & 156.46 & -5.89 & 165 & 16.52 & 190.73 & -124.35 & 82.9 & 37.66 & 446.72 & -190.49 & 293.89 \\
\hline Zhuhai & 4.1 & 44.45 & 6.7 & 55.25 & 4.99 & 57.57 & -33.36 & 29.2 & 11.69 & 138.58 & -82.73 & 67.54 \\
\hline Shantou & 1.85 & 20.07 & -4.54 & 17.38 & 1.98 & 22.82 & -5.51 & 19.29 & 5.14 & 60.97 & -16.34 & 49.77 \\
\hline Shaoguan & 1.01 & 10.95 & -7.22 & 4.74 & 0.91 & 10.47 & 34.65 & 46.03 & 4.94 & 58.59 & 20.7 & 84.23 \\
\hline Foshan & 2.85 & 30.94 & 35.54 & 69.33 & 4.58 & 52.84 & 19.14 & 76.56 & 14.16 & 168.01 & -20.47 & 161.7 \\
\hline Jiangmen & 2.07 & 22.48 & -14.39 & 10.16 & 1.89 & 22.8 & 28.38 & 53.07 & 7.19 & 85.39 & 11.44 & 104.02 \\
\hline Zhanjiang & 1.37 & 14.89 & -7.29 & 8.97 & 1.33 & 15.34 & -0.37 & 16.3 & 3.68 & 43.65 & 26.59 & 73.92 \\
\hline Maoming & 1.17 & 12.67 & 11.94 & 25.78 & 1.79 & 20.61 & -9.96 & 12.44 & 4.32 & 51.21 & -24.96 & 30.57 \\
\hline Zhaoqing & 1.48 & 16.01 & 0.3 & 17.79 & 1.72 & 19.84 & 10.06 & 31.62 & 5.5 & 65.22 & 29.4 & 100.12 \\
\hline Huizhou & 1.33 & 14.48 & 18.54 & 34.35 & 2.21 & 25.47 & 25.83 & 53.51 & 7.97 & 95.36 & -33.38 & 69.95 \\
\hline Qingyuan & 0.81 & 8.71 & 10.66 & 20.18 & 1.31 & 15.17 & 21.97 & 38.45 & 5.2 & 61.62 & 36.79 & 103.61 \\
\hline Meizhou & 0.61 & 6.6 & 4.47 & 11.68 & 0.86 & 9.97 & 15.41 & 26.24 & 3.48 & 41.29 & 54.83 & 99.6 \\
\hline Shanwei & 0.61 & 6.61 & -3.98 & 3.24 & 0.56 & 6.5 & 3.77 & 10.83 & 1.83 & 21.77 & 22.28 & 45.88 \\
\hline Dongguan & 3.92 & 42.44 & -30.37 & 15.99 & 3.45 & 39.76 & 12.48 & 55.69 & 10.48 & 124.34 & 19.69 & 154.51 \\
\hline Heyuan & 0.6 & 6.47 & 3.05 & 10.12 & 0.8 & 9.24 & 3.35 & 13.39 & 2.47 & 29.29 & 64.96 & 96.72 \\
\hline Yangjiang & 0.66 & 7.17 & 3.51 & 11.34 & 0.89 & 10.27 & -0.74 & 10.42 & 2.43 & 28.81 & 20.01 & 51.25 \\
\hline Zhongshan & 2.41 & 26.11 & -2.46 & 26.06 & 2.7 & 31.22 & 0.75 & 34.67 & 7.63 & 90.5 & -27.57 & 70.56 \\
\hline Chaozhou & 0.79 & 8.58 & 1.78 & 11.15 & 0.98 & 11.3 & 6.83 & 19.11 & 3.21 & 38.06 & -12.98 & 28.29 \\
\hline Jieyang & 0.57 & 6.24 & -2.23 & 4.58 & 0.59 & 6.75 & 4.57 & 11.91 & 1.96 & 23.2 & 32.79 & 57.95 \\
\hline Yunfu & 0.61 & 6.59 & 5.09 & 12.29 & 0.88 & 10.25 & 2.72 & 13.85 & 2.68 & 31.73 & 51.8 & 86.21 \\
\hline
\end{tabular}

Table 1 shows that the deviation component $\mathrm{Pi}$ is positive in the cities of Guangdong. And in the dynamic comparative analysis of 2003/2006, 2006/2009, 2009/2012 stage, its structure deviation component is larger compared to its competitiveness deviation component. However, both of them were rising gradually, although Dongguan, Shaoguan and Shanwei had smaller fluctuations in value during the base period 2003 and 2006. The structure deviation component of Dongguan changed from 42.44 to 39.76 . The structure deviation component of Shaoguan changed from 10.95 to 10.47. The structure deviation component of Shanwei changed from 6.61 to 6.5 . But the structure deviation of other cities is big, indicating that the tourism structure advantage contributed enormously to the local tourism economy. Unlike other municipal areas, the deviation component of Guangzhou, Shenzhen, Zhuhai, Foshan and Dongguan had a greater advantage for the development of tourism industry. In this article, the base year is 2009 and the reporting year is 2012, the structural advantages of tourism for the economic development of the contribution rate $(\mathrm{Pi} / \mathrm{Gi})$ was respectively $89.2 \%, 152 \%, 205.2 \%, 103.9 \%, 80.5 \%$.

Table 2. The tourism industrial competence in 21 cities of Guangdong

\begin{tabular}{|c|c|c|c|c|c|c|c|c|c|c|c|c|c|c|c|c|c|c|c|c|c|}
\hline City & $\begin{array}{c}\text { He } \\
\text { yuan }\end{array}$ & $\left|\begin{array}{c}\text { Mei } \\
\text { zhou }\end{array}\right|$ & $\begin{array}{l}\text { Yun } \\
\text { fu }\end{array}$ & $\begin{array}{l}\text { Qing } \\
\text { yuan }\end{array}$ & \begin{tabular}{|c|} 
Jie \\
yang
\end{tabular} & $\begin{array}{l}\text { Guarg } \\
\text { zhou }\end{array}$ & \begin{tabular}{|l|} 
Zhao \\
qing
\end{tabular} & $\begin{array}{c}\text { Zhan } \\
\text { jiang }\end{array}$ & \begin{tabular}{|l} 
Shan \\
wei
\end{tabular} & \begin{tabular}{|l|} 
Shao \\
guan
\end{tabular} & $\begin{array}{l}\text { Yang } \\
\text { jiang }\end{array}$ & $\begin{array}{l}\text { Dong } \\
\text { guan }\end{array}$ & $\begin{array}{l}\text { Jiang } \\
\text { men }\end{array}$ & $\begin{array}{l}\text { Chao } \\
\text { zhou }\end{array}$ & $\begin{array}{c}\text { Shan } \\
\text { tou }\end{array}$ & $\begin{array}{c}\text { Fo } \\
\text { shan }\end{array}$ & \begin{tabular}{|c|} 
Mao \\
ning
\end{tabular} & $\begin{array}{c}\text { Zhong } \\
\text { shan }\end{array}$ & $\begin{array}{l}\text { Hui } \\
\text { zhou }\end{array}$ & $\begin{array}{l}\text { Zhu } \\
\text { hai }\end{array}$ & $\begin{array}{l}\text { Shen } \\
\text { zhen }\end{array}$ \\
\hline $\begin{array}{l}\text { The value } \\
\text { Di based } \\
\text { on } 2003 \\
\text { and } 2006\end{array}$ & 3.05 & $\left.4.47\right|^{5}$ & $5.09 \mid$ & $10.66 \mid$ & $|-2.23|$ & -18.2 & 0.3 & -7.29 & $|-3.98|-$ & $|-7.22|$ & 3.51 & -30.4 & $\mid-14.39$ & 9.78 & $-4.54 \mid$ & 35.54 & 11.94 & -2.46 & 18.54 & 6.7 & -5.89 \\
\hline $\begin{array}{l}\text { The value } \\
\text { Di based } \\
\text { on } 2006 \\
\text { and } 2009 \\
\end{array}$ & 3.35 & $|15.41|^{2}$ & 2.72 & 21.97 & 4. 57 & -21.2 & $|10.06|$ & -20.37 & $\left.3.77\right|^{3}$ & $34,65 \mid$ & -0.74 & 12.48 & 28.38 & 6.83 & $-5.51 \mid$ & 19.14 & $|-3.96|$ & 0.75 & 25.83 & $|-33.36|$ & -124.35 \\
\hline $\begin{array}{l}\text { The value } \\
\text { Di based } \\
\text { on } 2009 \\
\text { and } 2012 \\
\end{array}$ & 64.96 & $|54.83|^{5}$ & 51.8 & $36.79 \mid$ & 32.79 & 29.82 & 29.4 & 26.59 & $22.28 \mid$ & $20.7 \mid$ & 20.01 & 19.69 & 11.44 & -12.98 & $\mid-16.34$ & $\mid-20.47$ & -25 & $-27.6 \mid$ & $|-33.38|$ & $\mid-82.73$ & -190.49 \\
\hline Rank & 1 & 2 & 3 & 4 & 5 & 6 & 7 & 8 & 9 & 0 & 11 & 12 & 13 & 14 & 15 & 16 & 17 & 18 & 19 & 20 & 21 \\
\hline
\end{tabular}

From Table 2, according to the report, the top 8 tourism industry competitiveness of 21 cities in Guangdong Province was as follows: Heyuan, Meizhou, Yunfu, Qingyuan, Jieyang, Guangzhou, Zhaoqing and Zhanjiang. The last three are ranked in the following order: Huizhou, Zhuhai and Shenzhen. Through vertical analysis of 
three phases data, tourism industrial competitiveness of Heyuan, Meizhou, Yunfu, Jieyang, Zhaoqing and Shanwei have gradually increased. The competitiveness of Heyuan tourism were 3.05, 3.35 and 64.96 in three periods: 2003-2006, 2006-2009, 2009-2012. The tourism industrial competitiveness of Meizhou were 4.47, 15.41 and 54.83 during the three stages. The tourism industrial competitiveness of Yunfu were 5.09, 2.72 and 51.8 during the three stages. The tourism industrial competitiveness of Jieyang were $-2.23,4.57$ and 32.79 during the three stages. The tourism industrial competitiveness of Zhaoqing were $0.3,10.06$ and 29.4 during the three stages. The tourism industrial competitiveness of Shanwei were -3.98, 3.77 and 22.28 during the three stages. However, the tourism industrial competitiveness of Zhuhai and Shenzhen diminished rapidly. The tourism industrial competitiveness of Zhuhai was $6.7,-33.36$ and -82.73 during the three stages. The tourism industrial competitiveness of Shenzhen were $-5.89,-124.35$ and -190.49 during the three stages.

For further analysis, according to the classification of Guangdong economic zone, Heyuan, Meizhou, Yunfu, Qingyuan and Shaoguan belong to mountainous areas. These areas' competitive component deviation are all positive, which means tourism of Guangdong's mountainous areas has been developing during these years. Due to the implementation of the Guangdong Provincial tourism pro-poor policies and the financial support for the tourism development in mountainous areas, the tourism was able to benefit significantly, which makes the rapid development of mountain tourism.

Table 3. The value of 21 cities' $P_{i}$ and $D_{i}$ based on the base period 2009 and the reporting period 2012

\begin{tabular}{|c|c|c|c|c|c|c|c|c|c|c|c|c|c|c|c|c|c|c|c|c|c|}
\hline & \begin{tabular}{|c|} 
He \\
yuan
\end{tabular} & \begin{tabular}{|l|} 
Ilei \\
zhou
\end{tabular} & $\begin{array}{c}\text { Yun } \\
\text { fu }\end{array}$ & $\begin{array}{l}\text { Qing } \\
\text { yuan }\end{array}$ & $\begin{array}{c}\text { Jie } \\
\text { yang }\end{array}$ & $\begin{array}{c}\text { Guang } \\
\text { zhou }\end{array}$ & $\begin{array}{l}\text { Zhao } \\
\text { qing }\end{array}$ & $\begin{array}{l}\text { Zhan } \\
\text { jiang }\end{array}$ & \begin{tabular}{|l} 
Shan \\
wei
\end{tabular} & $\begin{array}{l}\text { Shao } \\
\text { guan }\end{array}$ & $\begin{array}{l}\text { Yang } \\
\text { jiang }\end{array}$ & \begin{tabular}{|l|} 
Dong \\
guan
\end{tabular} & $\begin{array}{c}\text { Jiang } \\
\text { men }\end{array}$ & $\begin{array}{l}\text { Chao } \\
\text { zhou }\end{array}$ & $\begin{array}{c}\text { Shan } \\
\text { tou }\end{array}$ & $\begin{array}{c}\text { Fo } \\
\text { shan }\end{array}$ & \begin{tabular}{|l|} 
Mao \\
ming \\
\end{tabular} & $\begin{array}{c}\text { Zhong } \\
\text { shan }\end{array}$ & $\begin{array}{l}\text { Hui } \\
\text { zhou }\end{array}$ & $\begin{array}{l}\text { Zhu } \\
\text { hai }\end{array}$ & $\begin{array}{l}\text { Shen } \\
\text { zhen }\end{array}$ \\
\hline $\mathrm{Pi}$ & 29.29 & 41.29 & 31.73 & 61.62 & 23.2 & 815.9 & 65.22 & 43.65 & $21.77 \mid$ & 758.59 & 28.81 & 124.3 & 85.39 & 38.06 & 60.97 & 168.01 & $51.21 \mid$ & 90.5 & 95.36 & 138.58 & 846.72 \\
\hline $\mathrm{Di}$ & 64.96 & 54.83 & 51.8 & 36.79 & 32.79 & 29.82 & 29.4 & 26.59 & 22.28 & 820.7 & 20.01 & 19.69 & 11.44 & -12.98 & $8-16.34$ & -20.47 & -25 & -27.57 & $7-33.38$ & -32.73 & -190.4 \\
\hline
\end{tabular}

Table 4. The value of 21 cities' $\mathrm{PD}_{\mathrm{i}}$ and $\mathrm{N}_{\mathrm{i}}$ based on the base period 2009 and the reporting period 2012

\begin{tabular}{|c|c|c|c|c|c|c|c|c|c|c|c|c|c|c|c|c|c|c|c|c|c|}
\hline & \begin{tabular}{|c|} 
He \\
yuan
\end{tabular} & $\begin{array}{l}\text { Mei } \\
\text { zhou }\end{array}$ & $\begin{array}{l}\text { Yun } \\
\text { fu }\end{array}$ & $\begin{array}{l}\text { Qing } \\
\text { yuan }\end{array}$ & $\begin{array}{c}\text { Jie } \\
\text { yang }\end{array}$ & $\left|\begin{array}{c}\text { Guang } \\
\text { zhou }\end{array}\right|$ & $\begin{array}{l}\text { Zhao } \\
\text { qing }\end{array}$ & $\begin{array}{l}\text { Zhan } \\
\text { jiang }\end{array}$ & \begin{tabular}{|c|c} 
Shan & $S$ \\
wei & $g$
\end{tabular} & $\begin{array}{l}\text { Shas } \\
\text { guan } \\
j\end{array}$ & & & & & & $\begin{array}{c}\text { Fo } \\
\text { shan }\end{array}$ & \begin{tabular}{|l|}
$l l a o$ \\
ming
\end{tabular} & $\begin{array}{c}\text { Zhong } \\
\text { shan }\end{array}$ & & $\begin{array}{l}\text { Zhu } \\
\text { hai }\end{array}$ & \\
\hline$P$ & & .12 & .53 & 98.41 & 55.99 & 845.7 & 94.62 & 70.24 & 44.05 & 9.294 & 48.82 & 144 & 96.83 & 25.08 & 44.63 & 147.54 & \begin{tabular}{|l}
26.25 \\
\end{tabular} & 62.93 & 61.98 & 55.85 & 256.23 \\
\hline $\mathrm{Ni}$ & 2.47 & 3.48 & 2.68 & 5.2 & 1.96 & \begin{tabular}{|c|}
68.79 \\
\end{tabular} & \begin{tabular}{|l|}
5.5 \\
\end{tabular} & 3.68 & 1.83 & 4.91 & 2.43 & 10.48 & 7.19 & 3.21 & 5.14 & 14.16 & 4.32 & 7.63 & 7.97 & 11.69 & 37.66 \\
\hline
\end{tabular}

From Figure 1, there are 13 cities in Guangdong region in the first quadrant. They are Heyuan, Meizhou, Yunfu, Qingyuan, Jieyang, Guangzhou, Zhaoqing, Zhanjiang, Shanwei, Shaoguan, Yangjiang, Dongguan and Jiangmen; The remaining eight cities are in the second quadrant. They are Chaozhou, Shantou, Foshan, Maoming, Zhongshan, Huizhou, Zhuhai and Shenzhen. Regions distributed in the first quadrant show that the regions have a good industrial base. The tourism industry growth rate in these areas is greater than the average growth rate of the province's tourism industry. Structure and competitive advantages of its tourism industry show obvious advantages. Structural advantages and competitive advantages contributed largely to the growth of the industry. The structural advantages of Guangzhou's tourism industry has an outstanding contribution compared to competitive advantages. While regions located in the second quadrant indicate that the region's tourism industry foundation has structural advantages, rather than having competitive advantages. Status of the area in the whole of Guangdong's tourism industry is in decline. Among them, Shenzhen and Zhuhai take obvious advantages of tourism industry structure, and lack very competitive advantages, their structural advantages for the development of tourism has a greater contribution. However, the lack of competitive advantages has greatly restricted the rapid development of the tourism industry. As a whole, no cities were located in the third or fourth quadrant. This indicates that the basis of tourism industry in Guangdong Province is not bad, the entire structure of the tourism industry in Guangdong Province has obvious advantages. Guangdong Province has obvious structure advantages. And some of the cities (Di cities less than 0 ) restricted the further development of the tourism industry due to the lack of competitive advantages.

The regions located in the first quadrant are the regions which have been developed fast in recent years. As can be seen, Guangdong Province's 21 cities are located in the first quadrant. For cities which are far away from the zero point of the coordinates, such as Guangzhou, Shenzhen, Dongguan and Foshan, their tourism competitive advantages doesn't measure up to Heyuan, Meizhou and Yunfu. But their structural advantages make up for their 
lack of competitiveness, putting these cities at the forefront of Guangdong Province. The regional advantages in these areas are still more evident.

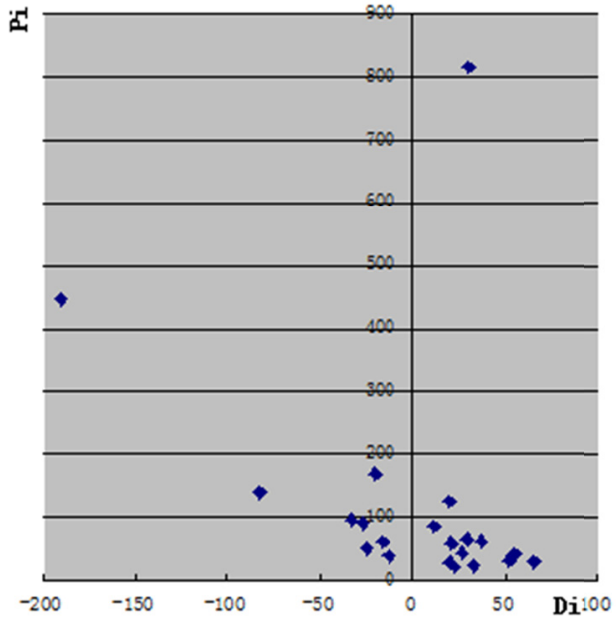

Figure 1. The regional deviation analysis

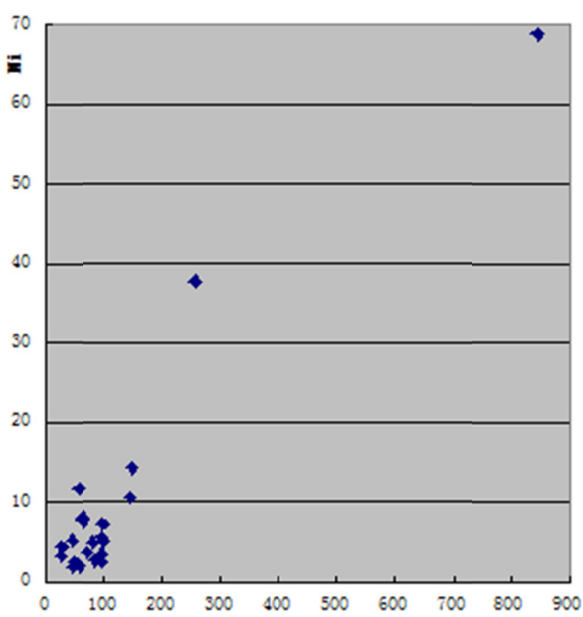

Figure 2. The regional advantage PDi analysis

\section{Results and Discussion}

The above analysis shows that there is big difference in structure advantage, competitive advantage and structure contribution of the regional tourism industry in Guangdong province. Therefore, there needs to be different optimization adjustment for different areas to eliminate restrictive factors for regional tourism industry development and enhance the overall strength of Guangdong tourism industry.

First of all, the areas with sound foundation, strong competitiveness and obvious structural advantage (not only structure components but also competitiveness components which are all greater than zero) need to maintain or strengthen their structure and competitive advantage of tourism industry. The analysis also indicates that the structure deviation component and competitiveness deviation component of Zhaoqing, Qingyuan, Meizhou, Heyuan and Yunfu during the stages of 2003-2006, 2006-2009, 2009-2012 are positive, and the values are on the rise which shows these areas have good advantage in structure and competitiveness. Four out of the five cities which include Meizhou, Qingyuan, Heyuan and Yunfu belong to the mountainous areas, this is also due to the pro-poor tourism policy proposed in 2002 that promoted the development of mountainous areas' tourism. Guangdong province should continue to raise support for mountainous tourism, exploit tourism resources in mountainous area, improve its infrastructure construction, increase marketing efforts, maintain and strengthen the overall advantage of mountainous areas' tourism industry.

Second, the tourism industry competitiveness advantage of Maoming, Shenzhen, Zhuhai, Foshan and Shantou dropped significantly, and it shows a continuous declining trend during the three stages. Therefore, these areas should pay more attention to this weakening trend and discover reasons that lead to weaken or hinder its tourism development. In order to reverse the situation of the recession of tourism industry competitiveness, some measures can be taken to increase its tourist attraction, such as address weaknesses in tourism development, improve service quality, develop new tourism products, strengthen marketing, refine tourism image and so on. Due to the structural advantage of Guangzhou, Shenzhen, Zhuhai, Foshan and Dongguan - which can make up for its competitive disadvantage-the overall development level of these areas is at the forefront in Guangdong province. However, these areas should also notice the weakening trend of their tourism competitiveness, then take a series of measures to improve the regional tourism competitiveness contrapuntally.

Finally, the future tourism development of Chaozhou, Maoming and Shantou, which are cities which have neither tourism industry competitive advantage nor structural advantages over other cities, should find out the factors that affect tourism industry development and enhance regional tourism industry from all aspects to make the tourism develop in a sustainable and healthy way.

After tourism structure and competitiveness analysis of 21 cities in Guangdong by SSA, we can have a general understanding on tourism development in these areas and offer some trend information to make reference for adjustment of regional distribution and its structure. In retrospect, SSA model still belongs to quantitative 
descriptive model, it can't fully and clearly explain underlying reasons for tourism structure and competitive advantages. Because of this, it needs to make a comprehensive analysis combined with regional tourism industry policy, tourism investment, tourism events and so on, find out the advantages and disadvantages of tourism industry development, thus we can keep the advantages and make up for the disadvantages to promote the overall development.

\section{References}

Creamer, D. (1943). Shifts of manufacturing industries. Industrial Location and National Resources, 85-104.

Dunn, \& Edger, S. (1960). A statistical and analytical technique for regional analysis. Papers in Regional Science, 6(1), 97-112. http://dx.doi.org/10.1111/j.1435-5597.1960.tb01705.x

Chiang, S. H. (2012). Shift-share Analysis and International Trade. Annals of Regional Science, 49(3), 571-588. http://dx.doi.org/10.1007/s00168-011-0465-1

Márquez, M. A., Ramajo, J. L., \& Hewings, G. J. D. (2009). Incorporating Sectoral Structure into Shift-share Analysis. Growth \& Change, 40(4), 594-618. http://dx.doi.org/10.1111/j.1468-2257.2009.00502.x

Mayor, M., \& López, A. (2008). Spatial shift-share analysis versus spatial filtering: An application to Spanish employment data. Empirical Economics, 34(1), 123-142. http://dx.doi.org/10.1007/s00181-007-0167-9

He, S. Q. (2012). Competition among ASEAN members in the East Asia Market an Extension to Shift-share Analysis. Journal of Economic Studies, 39(5), 576-589. http://dx.doi.org/10.1108/01443581211259482

Zhou, Q. Y., \& Liu, Z. X. (1989). Regional Economics. Beijing: China Renmin University Press.

Li, L. P., \& Zuo, X. G. (2010). The Dynamic Spatial Shift-share Method and Analysis on the Competitiveness of Hubei's industries. Economic Problems, (9), 117-122.

Mehregan, N., Asgary, A., \& Rezaei, R. (2012). Effects of the Bam earthquake on employment: A shift-share analysis. Disasters, 36(3), 420-438. http://dx.doi.org/10.1111/j.1467-7717.2011.01268.x

Liu, R. F., \& Moini, N. (2015). Benchmarking Transportation Safety Performance via Shift-Share Approaches. $\begin{array}{llllll}\text { Journal of Transportation Safety } \& \text { Security, } & 7(2), & \text { 124-137. }\end{array}$ http://dx.doi.org/10.1080/19439962.2014.940478

Hisyam, H. M. K., Rashid, Z. A., \& Hamid, K. A. (2011). East Coast Economic Region from the Perspective of Shift-share Analysis. International Journal of \& Society, 12(1), 79-88.

Zhang, C. Y. (2008). SSM-Aided Research on Industrial Competitiveness of Industry in Hubei Province. Journal of Wuhan University of Technology, 29(11), 152-155.

Lv, S., Wang, Y. M., Gong, W., \& Cheng, X. (2006). A SSM Analysis on the Structure of Tourism Market-A Case Study on Shanghai Oversea Tourism Market. Tourism Tribune, 21(11), 60-64.

Yasin, M., Alavi, J., Sobral, F., \& Lisboa, J. (2004). A Shift-Share Analysis Approach to Understanding the Dynamic of the Portuguese Tourism Market. Journal of Travel \& Tourism Marketing, 17(4), 11-22. http://dx.doi.org/10.1 300/J073v17n04_02

Yang, X. J., Ma, X. L., \& Huo, Y. P. (2005). A SSM Analysis on Rationality of Sector Structure of Tourism Industr. Human Geography, 20(1), 49-52.

Hu, Y. C., Wang, Q. S., \& Qian, Y. Y. (2008). Ananlysis of Industrial Structure of Tianjin International Tourism Based on SSM. Journal of Harbin University of Commerce, (1), 111-115.

Toh Rex, S., Khan, H., \& Lim, L. L. (2004). Two-Stage Shift-Share Analyses of Tourism Arrivals and Arrivals by Purpose of Visit: The Singapore Experience. Journal of Travel Research,43(1):57-66.http://dx.doi.org/10.1177/0047287504265513

He, T, X., Zhu, X., \& Zou, X. C. (2005). A Study on the Industrial Structure Benefit of Hunan Province. Economic Geography, 25(3), 333-337.

Yang, X. Y., \& Chen, C. (2006). Analysis of Structural Benefit and Competitiveness of Jiangsu's Service Industry. Resources and Environment in the Yangtze Basin, 15(4), 415-420. 


\section{Copyrights}

Copyright for this article is retained by the author(s), with first publication rights granted to the journal.

This is an open-access article distributed under the terms and conditions of the Creative Commons Attribution license (http://creativecommons.org/licenses/by/3.0/). 